\title{
PENGARUH LITERASI KEUANGAN KECERDASAN SPIRITUAL DAN PENDIDIKAN KEUANGAN DI KELUARGA TERHADAP PENGELOLAAN KEUANGAN MAHASISWA
}

\author{
Madelberta Resma Nugraheni Sigo \\ e-mail: madelbertsresma95@gmail.com \\ Lilik Sri Hariani \\ e-mail: liliksrihariani@unikama.ac.id \\ Walipah \\ e-mail:walipah@unikama.ac.id
}

\begin{abstract}
(Program Studi Pendidikan Ekonomi, Fakultas Ekonomika dan Bisnis, Universitas Kanjuruhan, Malang)
\end{abstract}
\begin{abstract}
This study aims to analyze the effect of financial literacy, spiritual intelligence, and financial education in families on the financial management of students of Economic Education in Kanjuruhan University Malang. This type of research uses quantitative research, using multiple linear regression. The population in this study were all students of Economic Education at Kanjuruhan University Malang, totaling 198 students with a research sample of 65 students. The sampling technique in this study used quota sampling. The data obtained were analyzed using the SPSS application version 16.00 for windows. Based on the results of the analysis it is known that there is a significant simultaneous and partial effect between financial literacy, spiritual intelligence, and financial education in families on the financial management of students of Economic Education at Universitas Kanjuruhan Malang
\end{abstract}

Keywords : Financial Literacy, Spiritual Intelligence, Financial Education in Families, Financial Management

\begin{abstract}
Abstrak: Penelitian ini bertujuan untuk menganalisis pengaruh literasi keuangan, kecerdasan spiritual, dan pendidikan keuangan di keluarga terhadap pengelolaan keuangan mahasiswa Pendidikan Ekonomi Universitas Kanjuruhan Malang. Jenis penelitian ini menggunakan penelitian kuantitatif, dengan menggunakan regresi linear berganda. Populasi dalam penelitian ini adalah semua mahasiswa Pendidikan Ekonomi Universitas Kanjuruhan Malang yang berjumlah 198 mahasiswa dengan sampel penelitian yang berjumlah 65 mahasiswa. Teknik pengambilan sampel dalam penelitian ini menggunakan sampel kuota (quota sampling). Data yang diperoleh dianalisis dengan menggunakan aplikasi SPSS versi 16.00 for windows. Berdasarkan hasil analisis diketahui bahwa terdapat pengaruh yang signifikan secara simultan dan parsial antara literasi keuangan, kecerdasan spiritual, dan pendidikan keuangan di keluarga terhadap pengelolaan keuangan mahasiswa Pendidikan Ekonomi Universitas Kanjuruhan Malang.
\end{abstract}

Kata kunci : Literasi Keuangan, Kecerdasan Spiritual, Pendidikan Keungan di Keluarga, pengelolaan Keuangan 


\section{PENDAHULUAN}

Perencanaan keuangan sangat penting dilakukan oleh semua kalangan. Karena perencanaan keuangan merupkan hal yang utama dalam pengelolaan keuangan. Sebelum melakukan pengelolaan keuangan terlebih dahulu kita harus merencanakannya secara matang agar tidak terjadi kekurangan. Dalam kehidupan sehari-hari pengelolaan keuangan yang baik sangat dibutuhkan. Terlebih bagi mahasiswa, sebagai mahasiswa pendidikan ekonomi kita harus mampu mengelola keuangan kita dengan sebaik mungkin agar terpenuhinya semua kebutuhan kita. Menurut Wulandari dan Hakim (2015) mengatakan salah satu kecerdasan yang harus dimiliki oleh mahasiswa yaitu kecerdasan finansial, yang merupakan kecerdasan untuk mengelola keuangan pribadinya dengan baik. Sebagai mahasiswa kita sudah dibekali ilmu untuk mengelola keuangan pribadi dengan baik, sehingga kita harus mampu mengelola keuangan pribadi kita agar mampu menunjukan bahwa ilmu yang kita peroleh tidak sia-sia.

Literasi keuangan atau pengetahuan tentang keuangan sangat dibutuhkan dalam pengelolaan keuangan agar kita mampu memilah-milah pengelolaan keuangan yang baik dan benar. Literasi keuangan merupakan suatu pengetahuan atau ketrampilan sikap dan perilaku seseorang dalam menentukan sebuah keputusan dalam pengelolaan keuangan agar tercapainya kesejahteraan keuangan yang diinginkan oleh setiap orang. Dengan adanya literasi keuangan kita mampu mengetahui cara mengelola keuangan pribadi dengan baik, karena dengan memiliki literasi keuangan yang baik maka kita mampu mengelola keuangan pribadi kita dengan baik juga. Menurut Rasyid (2012) mengatakan literasi keuangan merupakan kebutuhan utama yang dibutuhkan oleh setiap orang agar mampu terhindar dari masalah keuangan. Masalah keuangan merupakan hal yang paling dihindari oleh semua orang. Siapa sih yang mau mengalami kekurangan uang?, tentunya tidak ada yang mau bukan. Oleh sebab itu kita harus pintar-pintar dalam mengelola keuangan agar terhindar dari masalah keuangan. Sedangkan menurut Manurung (2009) literasi keuangan merupakan sprangkat ketrampilan dalam pengelolaan keuangan serta pengetahuan yang dimiliki seseorang yang memungkinkan setiap individu mampu mangambil sebuah keputusan keuangan yang efektif dengan menggunakan sumber daya yang tinggi dari tingkat kecerdasan spiritual, untuk memaknai sikap spiritual dalam kehidupan sehari-hari, dan dengan menggunakan kecerdasan spiritual yang tinggi untuk memecahkan masalah agar menjadi lebih terarah. Dalam pengelolaan keuangan hal yang dibutuhkan yaitu tingkat literasi keuangan yang tinggi, kecerdasan spiritual yang baik, serta pendidikan keuangan dikeluarga yang baik sejak dini. Setiap orang sudah pasti memiliki kecerdasan spiritual.

Peter (2012) kecerdasan spiritual merupakan pengetahuan atau kecerdasan yang menilai bahwa tindakan atau jalan hidup seseorang memiliki makna dan dan nilai yang tinggi. Sehingga kita sebagai seorang manusia harus sadar dan tahu bahwa hidup kita ini memiliki nilai yang bermakna agar kita harus mampu menghargai hidup kita setiap tindakan serta perbuatan yang kita lakukan harus memiliki nilai dan makna. Dengan adanya kecerdasan spiritual yang baik dalam penelolaan keuangan mampu mendorong kita lebih bijak dalam mengelola keuangan pribadi kita, karena dengan kecerdasan spiritual kita bisa berpikir dan bertindak positif dalam mengelola keuangan. Selain literas keuangan dan kecerdasan spiritual juga terdapat pendidikan keuangan di keluarga. Pendidikan keuangan dikeluarga sangat dibutuhkan bagi setiap orang. Sebelum seseorang mengenal pendidikan yang lebih luas di sekolah, setiap orang sudah pasti terlebih dahulu mengenal pendidikan yang diberikan oleh kedua orang tuanya.

Orang tua wajib menanamkan pendidikan dasar mengenai keuangan untuk anaknya. Agar anak tersebut memiliki bekal yang kuat dikemudian hari, karena pendidikan sejak dini sangat mudah diserap oleh anak-anak. Menurut Chotima dan Suci (2017) keluarga merupakan orang pertama yang dikenal oleh seorang anak sebelum mengenl lingkungan luas. Peran orang tua sangat penting dalam sebuah pendidikan, salah satunya adalah pendidikan pengelolaan keuangan. Apabila dalam sebuah 
keluarga mampu mengelola keuangan keluarganya dengan baik maka hal tersebut dapat berdampak positif pada anaknya. Akan lebih baik jika orang tua menanamka pendidikan keuangan pada anaknya sejak sedini mungkin karena pada saat tersebut merupakan waktu yang tepat bagi seorang anak dalam menyerap pengetahuan. Tujuan penelitian ini adalah: 1) Untuk mengetahui dan menganalisis pengaruh literasi keuangan, kecerdasan spiritual dan pendidikan keuangan di keluarga terhadap pengelolaan keuangan mahasiswa Pendidikan Ekonomi Universitas Kanjuruhan Malang, 2) Untuk mengetahui dan menganalisis pengaruh literasi keuangan terhadap pengelolaan keuangan mahasiswa Pendidikan Ekonomi Universitas Kanjuruhan Malang, 3) Untuk mengetahui dan menganalisis pengaruh kecerdasan emosional terhadap pengelolaan keuangan mahasiswa Pendidikan Ekonomi Universitas Kanjuruhan Malang, 4) Untuk mengetahui dan menganalisis pengaruh pendidikan keuangan di keluarga terhadap pengelolaan keuangan mahasiswa Pendidikan Ekonomi Universitas Kanjuruhan Malang.

\section{TINJAUAN PUSTAKA}

Pengelolaan keuangan merupakan sebuah proses bagaimana sebuah individu maupun keluarga mampu mengatur keuangan pribadi dengan baik dan benar sehingga tidak terjadi kekuragan. Menurut cumins (2009) kemampuan seseorang mengelola keuangan menjadi salah satu faktor penting untuk menjadi sukses dalam hidup, sehingga pengetahuan akan pengelolaan keuangan yang baik dan benar menjadi penting bagi anggota masyarakat khususnya individu. Pengelolaan keuangan tidak hanya untuk suatu organsisasi atau instansi saja, akan tetapi pengelolaan keuangan juga dibutuhkan bagi diri kita sendiri agar dikemudian hari tidak terjadi masalah dalam hal pengeluaran keuangan yang tidak diinginkan. Menurut Naila dan Iramani (2013) pengelolaan keuangan adalah kemampuan seseorang dalam mengatur (perencanaan, penganggaran, pemeriksaan, pengelolaan, pengendalian, pencarian, dan penyimpanan). Masa depan seseorang bisa tercermin dari kemampuannya dalam mengelola keuangan. Pengetahuan yang minim akan hal ini bisa membuat orang gagal mengelola keuangan. Tidak peduli seberapa besar pendapatan yang diterima jika uang tidak dikelola dengan baik maka krisis keuangan pribadi dapat saja terjadi.

Literasi keuangan adalah penengetahuan atau kemampuan untuk mengelola keuangan. Literasi keuangan merupakan suatu hal yang penting untuk dimiliki dalam mengelola keuangan atau pendapatan yang dihasilkan oleh seseorang untuk menunjang kesejahteraannya di masa depan. Untuk mencapai kesejahteraan dan kemakmuran setiap orang harus mampu mengelola keuangan dengan baik. Menurut Manurung (2009) literasi keuangan adalah seprangkat ketrampilan dan pengetahuan yang memungkinkan seorang individu untuk membuat keputusan yang efektif dengan menggunakan semua sumber daya mengusahakan tingkat yang tinggi dari kesadaran spiritual, memahami makna spiritual dalam aktifitas setiap hari, menggunakan sumberdaya spiritual untuk memecahkan masalah-masalah dan menjadi berbudi pekerti yang luhur. Menurut Monticone (2010) dalam penelitiannya menjelaskan bahwa tingkat literasi keuangan seseorang di pengaruhi oleh : (1) Karakterisik Sosio-Demografi, (2) Latar Belakang Keluarga, (3) Kekayaan, (4) Preferensi Waktu.

Kecerdasan spiritual (SQ) merupakan kecerdasan atau kemampuan untuk menghadapi dan memecahkan masalah makna kehidupan, nilai-nilai dan keutuhan diri yaitu kecerdasan untuk menempatkan diri dalam konteks makna yang lebih luas dan kaya, kecerdasan untuk menilai bahwa tindakan atau jalan hidup seseorang lebih bermaka dibandingkan dengan yang lain. Menurut Peter (2012) kecerdasan spiritual merupakan kecerdasan yang menilai bahwa tindakan atau jalan hidup 
seseorang lebih bernilai dan bermakna. Kecerdasan spiritual merupakan kecerdasan yang membantu menyembuhkan dan membangun diri manusia secara utuh. Kecerdaan spiritual adalah landasan yang diperlukan untuk memfungsikan IQ dan EQ secara efektif. Kecerdasan spiritual sendiri adalah kecerdasan jiwa atau batin untuk tumbuh menjadi manusia seutuhnya dengan selalu berpikir positif dalam menyikapi setiap peristiwa yang dialaminya. Kecerdasan spiritual (SQ) akan membawa anda menjadi orang yang bijak sana sehingga mengerti makna kehidupan. Kecerdasan spiritual (SQ) memiliki ciri-ciri umum yang membedakannya dengan kecerdasan lain. Yaitu: 1) Kemampuan untuk berpikir diluar materi fisik dan diluar panca indra, 2) Kemampuan untuk mengungkapkan dan menemukan makna dari suatu hal, 3) Kemampuan untuk mengabdi pada sesama dan membuat dunia menjadi lebih baik.

Kecerdasan spiritual (SQ) memiliki tiga aspek utama yang dijadikan landasan dalam mengembangkan spiritualitas. Ketiga aspek tersebut adalah sebagai berikut: 1) Mengidentifikasi bahwa ada kekuatan spiritual yang lebih tinggi. Artinya bahwa Kecerdasan spiritual (SQ) percaya bahwa ada kekuatan spiritual yang lebih tinggi dari apapun yang mengatur alam semesta beserta isinya; 2) Memahami hukum sebab akibat. Kecerdasan spiritual (SQ) mengajarkan pada anda untuk betanggung jawab terhadap setiap perbuatan yang anda lakukan; 3) Tidak terikat. Kecerdasan spiritual (SQ) berasal dan bersumber dari batin dan jiwa seseorang. Ini akan berbeda dari satu orang dengan orang yang lain. Kecerdasan spiritual (SQ) tidak terikat oleh bentuk dan hasil. Kecerdasan spiritual (SQ) lebih mengutamakan kedamaian dan kesejahteraan batin.

Memiliki kecerdasan spiritual yang tinggi akan memberikan banyak manfaat dalam kehidupan kita. Berikut ada beberapa manfaat yang kita dapatkan dari kecerdasan spiritual: 1) Membantu anda melihat hal-haldari sudut pandang yang lebih luas dan kompleks; 2) Membantu berpikir lebih jernih; 3) Membantu pikiran lebih tenang; 4) Membuka wawasan dan motifasi anda tentang bagaimana cara memaknai hidup; 5) Menurunkan sikap egoisme dalam diri; 6) Memunculkan sikap menghargai orang lain dengan menempatkan orang lain diposisi yang lebih tinggi dari pada diri sendiri; 7) Menyadari pentingnya nilai-nilai kehidupan seperti keadilan, kejujuran, kebenaran, dan kehormatan; 8) Memunculkan sikap belas kasih terhadap orang lain; 9) Memunculkan sikap selalu bersyukur terhadap apa yang dimiliki; 10) Memunculkan rasa cinta kasih terhadap diri sendiri, orang lain maupun pada alam semesta.

Pendidikan adalah suatu pengetahuan yang dimiliki oleh setiap orang, yang mampu membuat orang tersebut berpikir jernih untuk melakukan segala sesuaitu yang ingin dia lakukan. Ariyani (2016) mengatakan Pusat pendidikan yang pertama adalah lingkungan keluarga, pendidikan diligkungan keluarga sangat efektif untuk diberikan kepada ana dibawah umur agar anak mampu berfikir kearah kecerdasan, budi pekerti atau kepribadian serta persiapan hidup dimasyarakat. Orang tua akan menjadi contoh untuk anaknya, anak biasanya akan menirukan apa saja yang dilakukan oleh orang tua. Sebagai orang tua harus mampu memberikan contoh yang baik untuk anaknya. Kebiasaan yang baik seharusnya diajarkan orang tua kepada anaknya sejak sedini mungkin agar anaknya menjadi terbiasa dengan hal baik.

Orang tua sebaiknya memperhatikan pendidikan anak-anaknya karena peran orang tua angat penting dalam proses pendidikan bagi mereka. Orang tua mampu meneydiakan kebutuhan material anak-anaknya secara memuaskan tetapi kebutuhan pendidikan anak jarang terpenuhiperan orang tua dalam pendidikan anak sangat penting karena pendidikan merupakan modal utama yang 
harus dimiliki oleh setiap orang. Seorang manusia belajar sejak lahir dan terus belajar sepanjang hayat (long life education). Dalam proses belajar itulah, seseorang akan berproses menjadi lebih baik sepanjang siklus hidup. Spesifiknya, belajar menjadi (learning to be) merupakan penentu bagaimana berhasil atau tidaknya seseorang dalam hidup yang diperankan. Selanjutnya, untuk belajar, terdapat berbagai tempat yang dapat dijadikan tempat belajar dan salah satunya adalah belajar dalam keluarga. Belajar dalam keluarga berarti individu belajar dari anggota keluarga yang mana salah satunya adalah belajar mengelola uang dari orang tua.

Kajian empirik yang digunakan dalam penelitian ini adalah: 1) Mega Dwi Rani Siahaan (2013). Tentang pengaruh literasi keuangan terhadap perilaku pengelolaan keuangan pada mahasiswa perguruan tinggi di surabaya; 2) Muhammad Sukroni (2017). Tentang pengaruh literasi keuangan dan kecerdasan spiritual pada pengelolaan keuangan mahasiswa di surabaya; 3) Peter Garlans Sina dan Andris Noya pada tahun 2012, tentang pengaruh kecerdasan spiritual terhadap pengelolaan keuangan pribadi; 4) Yeni Anggraeni Putri, 2017. Pengaruh pengetahuan keuangan dan pendidikan keuangan di keluarga terhadap pengelolaan keuangan mahasiswa di surabaya; 5) Susan Tee Suan Chin, RN. Anantharaman dan David Yoon Kin Tong, 2011. Tentang the roles of emotional inteligence and spiritual inteligence at the work place; 6) Annamaria Lusardi, Olifia S. Mitchaell, And Vilsa Curto, 2010. Tentang financial literacy among the young.

Menurut OJK (2014) literasi keuangan adalah deretan proses atau kegiatan untuk meningkatkan pengetahuan, ketrampilan setiap orag agar mampu mengelola keuangan dengan baik dan benar, sesuai dengan apa yang mereka butuhkan dan memberkan manfaat. Kecerdasan spiritual (SQ) adalah kecerdasan untuk menghadapi suatu masalah hidup, berpikir positif, dan mampu memecahkan suatu masalah, dan berpikir bahwa hidup memiliki arti yang bermakna. Keluarga sebagai satuan masyarakat terkecil merupakan salah satu tempat belajar yang signifikan bagi perkembangan karakter anak hingga menjadi dewasa. Dengan adanya literasi keuangan yang tinggi, kecerdasan spiritual yang tinggi dan pendidikan keuangan di keluarga yang baik maka seorang mahasiswa akan mampu mengelola keuangannya dengan baik dan bijak.

Atkinson dan Messy (2011) menyatakan bahwa literasi keuangan didefinisikan sebagai kombinasi dari kesadaran, pengetahuan, ketrampilan, sikap, dan perilaku yang diperlukan untuk membuat keputusan yang tepat sehingga tercapai kesejahteraan keuangan yang diinginkan setiap individu. Nyoman (2015) menyatakan bahwa literasi keuangan berpengaruh positif dan signifikan terhadap perilaku keuangan mahasiswa. berpengaruh positif yang diartikan bahwa semakin tinggi tinggi tingkat literasi keuangan seseorang maka semakin baik perilaku keuangannya. Pengetahuan keuangan didefinisikan sebagai kecerdasan atau kemampuan seseorang dalam mengelola keuangan.

Karfov (2010) menyatakan bahwa setiap orang membutuhkan kecerdasan spiritual dalam mengelola keuangan (personal finance) karena dapat menimbulkan sifat filantropis. Nalarnya adalah charity atau amal disebut dengan memberikan sebagian harta yang kita miliki kepada pihak yang lebih membutuhkan.

Pendidikan yang paling utama didapatkan oleh seorang anak berasal dari orang tua. Orang tua sangat berperan penting dalam pendidikan seorang anak, dalam hal ini adalah pendidikan keuangan. Orang tua harus mampu mengenalkan pendidikan keuangan kepada anaknya sejak sedini mungkin karena pada saat itulah seorang anak mampu menyerap apa yang diajarkan dengan baik. 
Setiap orang tua harus mampu menunjukan kebiasaan baik kepada anaknya, karena setiap anak akan selalu meniru apa yang dilakukan orang tuanya.

\section{METODE}

Penelitian ini menggunakan pendekatan kuantitatif, dengan jenis penelitian ex-post-facto, karena peelitian ini menggunakan variabel yang telah terjadi dan tidak perlu ada perlakuan khusus terhadap variabel yang telah diteliti. Populasi dalam penelitian ini adalah seluruh mahasiswa program studi Pendidikan Ekonomi Universitas Kanjuruhan Malang sebanyak 198 mahasiswa. Teknik pengambilan sampel dalam penelitian ini menggunakan sampel kuota atau Quota sample yaitu dengan cara tidak mendasarkan diri pada strata atau daerah tetapi mendasarkan diri pada jumlah yang sudah ditentukan. Dalam pengumpulan data peneliti menghubungkan subjek yang memenuhi persyaratan ciri-ciri populasi, tanpa menghiraukan dari mana asal subjek tersebut (asal masih dalam populasi). Biasanya yang dihubungkan adalah subjek yang mudah ditemui, agar pengumpulan datanya lebih mudah, sehingga jumlah sampel yang digunakan dalam penelitian ini yaitu sebanyak 65 mahasiswa. Instrumen penelitian ini menggunakan angket atau kuesioner. Analisis penelitian ini menggunakan regresi linear berganda dengan bantuan aplikasi SPSS versi 16.00 for windows.

\section{HASIL DAN PEMBAHASAN}

Hasil penelitian yang diperoleh dari pengumpulan data dengan instrumen penelitian dari skala likert. Analisis regresi linear berganda menggunakan aplikasi SPSS versi 16.00 for windows yang dilakukan melalui beberapa tahap untuk mengetahui besarnya pengaruh antara variabel-variabel independen yang terdiri dari: literasi keuangan, kecerdasan spiritual, dan pendidikan keuangan di keluarga terhadap variabel dependen yaitu pengelolaan keuangan

Menjawab hipotesis yang sudah disebutkan, dapat diuji dengan salah satunya menggunakan uji F. Berikut adalah pengaruh secara simultan (bersama-sama) antara seluruh variabel bebas dengan variabel terikat. Adapun hasilnya dapat ditujukan pada tabel 2.

Tabel 2

Hasil Uji F (Uji Secara Simultan)

ANOVA $^{b}$

\begin{tabular}{|c|c|c|c|c|c|c|}
\hline \multicolumn{2}{|c|}{ Model } & Sum of Squares & Df & Mean Square & $\mathrm{F}$ & Sig. \\
\hline & Regression & 3475.163 & 3 & 1158.388 & 56.485 & $.000^{\mathrm{a}}$ \\
\hline & Residual & 1250.991 & 61 & 20.508 & & \\
\hline & Total & 4726.154 & 64 & & & \\
\hline
\end{tabular}

Sumber: Data Diolah 2018

Hasil uji F tabel 2 diperoleh FHitung sebesar 56.485 dengan tingkat signifikan 0.000. Variabel literasi keuangan (X1), Kecerdasan spiritual (X2), dan pendidikan keuangan di keluarga (X3) secara bersama-sama atau simulan mempengaruhi pengelolaan keuangan mahasiswa $(\mathrm{Y})$ karena tingkat signifikan dibawah 0.05 . 
Mahasiswa Pendidikan Ekonomi Universitas Kanjuruhan Malang memiliki pengelolaan keuangan yang baik. Pengelolaan keuangan merupakan bagaimana cara kita mengatur dan mengelola keuangan bulanan kita agar bisa terarah dan tidak terjadi kekurangan dikemudian hari. Dengan memiliki kemampuan pengelolaan keuangan yang tinggi kita mampu mengoptimalkan segala perencanaan pengeluaran yang akan dilakukan dalam sebulan, mampu meminimalisisr terjadi kekurangan di akhir bulan, dengan adanya literasi keuangan, kecerdasan spiritual dan pendidikan keuangan di keluarga maka kita mampu mencapai target pengelolaan keuangan yang diinginkan, serta mampu menghindari terjadinya penyimpangan terhadap pengalokasian keuangan pribadi.

Melihat pengaruh secara parsial atau pengaruh antara masing-masing variabeo bebas terhadap variabel terikat dengan menggunakan uji t. Hasil uji t dapat ditunjukan pada tabel 3.

Tabel 3

Hasil Uji t (Uji Secara Parsial)

\begin{tabular}{|l|r|r|l|}
\hline \multicolumn{1}{|c|}{ Variabel } & \multicolumn{1}{c|}{ t-hitung } & \multicolumn{1}{c|}{ Sig } & \multicolumn{1}{c|}{ Keterangan } \\
\hline Constant & 1.036 & .304 & \\
\hline Literasi keuangan (X1) & 2.741 & .008 & Signifikan \\
\hline Kecerdasan spiritual (X2) & 4.769 & .000 & Signifikan \\
\hline Pendidikan keuangan di keluarga (X3) & 2.095 & .040 & Signifikan \\
\hline
\end{tabular}

Sumber: Data diolah 2018

Pada tabel 3 nilai t-hitung variabel literasi keuangan (X1) sebesar 2.741 dengan tingkat signifikan sebesar 0.008. Karena tingkat signifikannya lebih kecil dari 0.05, maka variabel literasi keuangan (X1) berpengaruh terhadap pengelolaan keuangan (Y). Sehingga H2 diterima. Nilai thitung untuk variabel kecerdasan spiritual (X2) sebesar 4.769 dengan tingkat signifikan sebesar 0.000. Karena tingkat signifikannya lebih kecil dari 0.05, maka variabel kecerdasan spiritual (X2) berpengaruh terhadap pengelolaan keuangan (Y). Sehingga H3 diterima. Nilai t-hitung untuk variabel pendidikan keuangan di keluarga (X3) sebesar 2.095 dengan tingkat signifikan sebesar 0.040. Karena tingkat signifikannya lebih kecil dari 0.05, maka variabel pendidikan keuangan di keluarga (X3) berpengaruh terhadap pengelolaan keuangan (Y). Sehingga H4 diterima.

Literasi keuangan memiliki pengaruh terhadap pengelolaan keuangan, sebagian besar mahasiswa pendidikan ekonomi Universitas Kanjuruhan Malang memiliki literasi keuangan yang baik. Semakin tinggi literasi keuangan seseorang maka semakin baik orang tersebut dalam mengelola keuangannya. Karena literasi keuangan merupakan suatu dasar dalam pengelolaan keuangan. Literasi keuangan sangat dibutuhkan dalam pengelolaan keuangan, karena literasi keuangan merupakan dasar utama yang sangat dibutuhkan dalam pengelolaan keuangan. Tanpa ada literasi keuangan kita tidak mampu dalam mengelola keuangan, karena tidak memiliki dasar yang kuat dalam pengelolaan keuangan. Literasi keuangan wajib dimiliki oleh setiap orang. Literasi keuangan bertujuan untuk meningkatkan pengelolaan keuangan yang baik kepada setiap mahasiswa agar mampu mengelola keuangan yang baik dalam kehidupan sehari-harinya. Dengan adanya literasi keuangan yang baik mahasiswa mampu memahami bagaimana cara pengelolaan keuangan yang baik dan benar. Tanpa adanya literasi keuangan yang baik kita tidak mampu memahami suatu pengetahuan tentang keuangan, pengetahuan tentang cara mengelola keuangan dengan baik dan benar, pengetahuan 
tentang menyimpan uang yang baik dan benar, pengetahuan tentang membelanjakan uang dengan benar, sehingga kita tidak bisa mengelola keuangan dengan baik. Oleh karena itu literasi keuangan sangat penting bagi kehidupan kita. Sebagai mahasiswa Pendidikan Ekonomi kita harus memiliki literasi keuangan yang tinggi agar kita mampu mengelola keuangan yang baik dan benar. Karena literasi keuangan menjadi bekal kita dalam pengelolaan keuangan agar tidak terjadi masalah dalam keuangan di kemudian hari. Dalam penelitian ini dapat dikatankan mahasiswa pendidikan ekonomi Universitas Kanjuruhan Malang memiliki literasi keuangan yang baik, karena dapat dilihat pada hasil penelitian terdapat sebagian besar mahasiswa pendidikan ekonomi memiliki literasi keuangan yang baik.

Kecerdasan spiritual sangat dibutuhkan bagi setiap orang. Kecerdasan spiritual berperan penting dalam pengelolaan keuangan, karena dengan kecerdasan spiritual kita mampu berpikir lebih jernih dalam pengelolaan keuangan, mampu menurunkan sikap egoisme dalam diri, sehingga kita tidak lebih mementingkan keinginan kita, mampu menghargai orang lain. Dengan memiliki uang yang lebih kita tidak merasa sombong dan berbesar hati karena kita mampu mengontrol diri kita dengan kecerdasan spiritual yang kita miliki. Dengan memiliki kecerdasan spiritual yang tinggi kita juga mampu bersyukur dengan apa yang kita miliki, sehingga dalam pengelolaan keuangan kita tidak menjadi boros dalam membelanjakan, karena kita selalu memiliki rasa syukur dengan apa yang kita miliki. Penelitian ini menunjukan mahasiswa pendidikan ekonomi Universitas Kanjuruhan Malang memiliki kecerdasan spiritual yang baik dalam pengelolaan keuangan.

Pendidikan keuangan di keluarga sangat penting karena dapat memberikan bekal kepada anak agar mampu mengelola keuangan dengan baik dikemudian hari. Setiap orang tua pasti mengajarkan anaknya agar mampu mengelola keuangan dengan baik, menabung, dan tidak boros. Orang tua berkewajiban untuk mengembangkan potensi pengelolaan keuangan anak, karena di sekolah pembelajaran dalam pengelolaan keuangan pribadi penjelasannya tidak terlalu terperinci dan mendalam sehingga orang tua memiliki kewajiban untuk mengajarkan pengelolaan keuangan yang baik kepada anaknya. Pusat pendidikan utama seorang anak yaitu berasal dari orang tua. Jadi setiap perbuatan atau kebiasaan yang dilakukan oleh orang tua, anaknya akan meniru kebiasaan tersebut. Sehingga sebagai orang tau harus memberkan contoh yan baik kepada anaknya. Dengan adanya pendidikan keuangan di keluarga seorang anak menjadi mampu dalam pengelolaan keuangan sehingga anak tersebut tidak merasa kesusahan dalam mengelola keuagan ketika menginjak dewasa.Penelitian ini menunjukan pendidikan keuangan di keluarga berpengaruh terhadap pengelolaan keuangan mahasiswa pendidikan ekonomi Universitas Kanjuruhan Malang.

\section{KESIMPULAN}

Berdasarkan hasil analisis data dan pembahasan diatas dapat disimpulkan ada pengaruh secara simultan literasi keuangan, kecerdasan spiritual, dan pendidikan keuangan dikeluarga terhadap pengelolaan keuangan mahasiswa, ada pengaruh secara parsial literasi keuangan terhadap pengelolaan keuangan mahasiswa, ada pengaruh secara parsial kecerdasan spiritual terhadap pengelolaan keuangan mahasiswa, dan ada pengaruh secara parsial pendidikan keuangan dikeluarga terhadap pengelolaan keuangan mahasiswa. Literasi keuangan, kecerdasan spiritual, dan pendidikan keuangan dikeluarga berkontribusi sebesar $73.5 \%$ terhadap pengelolaan keuangan mahasiswa. 


\section{DAFTAR PUSTAKA}

Ariyani Dwi. Y. 2016. "Pentingnya Peran Orang Tua Terhadap Pendidikan Anak". Yogyakarta. http://almaata.ac.id/pentingnya-peran-orang-tua-terhadap-pendidikan anak/.

Atkinson, Adele, \& Flore-Anne Messy. 2011. "Assessing Financial Literacy In 12 Countres:An OECD/INFE International Pilot Exercies". Journal Of Pension Economics And Finance. Vol. 10, No. 04 Pp. 657-665.

Chin Susan Tee Suan. RN RN. Anantharaman dan David Yoon Kin Tong, 2011. "The Roles Of Emotional Inteligence and Spiritual Inteligence At The Work Place". Vol 2011.

Chotimah, Chusnul \& Suci Rohayati. 2017. "Pengaruh Pendidikan Keuangan Di Keluarga, Sosial Ekonomi Orang Tua, Pengetahuan Keuangan, Kecerdasan Spiritual, Dan Teman Sebaya Terhadap Manajemen Keuangan Pribadi Mahasiswa S1 Pendidikan Akuntansi Fakultas Ekonomi Universitas Negeri Surabaya". Surabaya.

Cummins, M.M. Haskel, J.H. Jenkins S.J. 2009. "Financial Attitudes And Spending". Habits Of University Freshmen Journal Of Economis And Economic Education Research. Vol.10 No. 1.

Karvof, A. 2010. "Kaya dengan CEPIL: Cara Cerdas Meraik Kekayaan Dan Keberkatan Finansial". Elex Media Komputindo. Jakarta.

Lusardi Annamaria, Olifia S. Mitchaell, And Vilsa Curto , 2010. “Financial Literacy Among The Young". Vol. 44, No. 2, 2010.

Manurung Jonni J., \& Adler H. Manurung, 2009. “Ekonomi Keuangan Dan Kebijakan Moneter CetakanPertama Jakarta: Salemba Empat.

Monticone Chiara. 2011. "Financial Literacy and Financial Advice": Theory and Empirical Evidence. $\mathrm{PhD}$ Thesis, Università degli Studi di Torino, Torino. Available at: http://arno.uvt.nl/show.cgi?fid=115261.

Naila Al Kholilah \& Rr. Iramani. 2013. "Studi Financial Managemen Behaviori Pada Masyarakat Surabaya". Journal Of Business And Banking, Vol. 3, No. 1, 69-80.

Nyoman Trisna Herawati. 2015. "kontribusi pemblajaran diperguruan tinggi dan Literasi keuangan terhadap perilaku keuangan mahasiswa". Jurnal pendidikan dan pengajaran, jilid 48, nomor 13, hlm 60-70.

Otoritas Jasa Keuangan. 2014. Siaran Pers OJK Dan LJK Dorong Layanan Keuangan Mikro Untuk Perluas Akses Keuangan Masyarakat. (Online). (http://www.ojk.go.id, diakses 16 Februari 2018).

Putri Yeni Anggraeni. 2017. "Pengaruh Pengetahuan Keuangan Dan PendidikanKeuangan Di Keluarga Terhadap Pengelolaan Keuangan Mahasiswa Di Surabaya". Artikel Ilmih.

Rasyid, Rosyeni. 2012. “Analisis Tingkat Literasi Keuangan Mahasiswa Program Studi Manajemen Fakultas Ekonomi Universitas Negeri Padang. Vol.1, No.2. Padang.

Siahaan Mega Dwi Rani, 2013. "Pengaruh Literasi Keuangan Terhadap Perilaku Pengelolaan Keuangan Pada Mahasiswa Perguruan Tinggi Di Surabaya". Artikel Ilmiah.

Sina, P. G. 2012. "Pengaruh Kecerdasan Spiritual Terhadap Pengelolaan Keuangan Pribadi". Jurnal Manajemen. Vol. 11 (2) : pp. 171-188.

Suharsimi, Arikunto. 2013. Prosedur Penelitian. Rineka Cipta.

Sukroni Muhammad. 2017. "Pengaruh Literasi Keuangan Dan Kecerdasan Spiritual Pada Pengelolaan Keuangan Mahasiswa Di Surabaya". Artikel Ilmih.

Wulandari. \& Lukman Hakim. 2015. “Pengaruh Love Of Money, Pendidikan Keuangan Dikeluarga, Hasil Belajar Manajemen Keuangan, dan Teman Sebaya Terhadap Manajemen Keuangan Pribadi Mahasiswa". Vol.3, No.3. Surabaya. 